Jenius: Jurnal of Education Policy and Elementary Education Issues

Vol.1, No.2, Desember 2020, pp. 54-62

\title{
ANALISIS PEMBELAJARAN DARING SELAMA PANDEMI COVID- 19 DI SEKOLAH DASAR SURAKARTA
}

\author{
Apriyana Yesy Tania \\ Pendidikan Profesi Guru, Universitas Muhammadiyah Surakarta \\ E-mail: apriyana.tania@gmail.com
}

\begin{abstract}
Online learning during the Covid-19 pandemic makes teachers have to rack their brains to innovate and be creative in channeling knowledge to students in various ways. This research was conducted in February 2021 at SD Muhammadiyah 1 Ketelan Surakarta. The objectives of this study: 1) determine the implementation of online learning strategies in the era of the COVID-19 pandemic in elementary schools; 2) knowing the difficulties experienced by teachers while implementing online learning in the era of the COVID-19 pandemic in elementary schools. The subject of this research is the homeroom teacher for class IIID. This type of research is a case study. Data collection techniques through structured interviews, observation and documentation. The validity of the data uses data triangulation using data reduction, data presentation, and verification. The results of this study are: 1) Online learning carried out according to school policy through zoom meetings every day at 08.00-10.45 is quite effective, this is evidenced by the midsemester score which shows the average is above the minimum limit; 2) Obstacles experienced during online learning in class are the teacher's not optimal in explaining the material, signal problems and there are still some students who do not have a personal smartphone to take part in online learning through zoom meetings because the smartphone is brought by parents, so the teacher always provides a zoom recording meetings and materials in the form of files.
\end{abstract}

Keywords: Learning Online; Pandemic Covid-19; Primary School

\begin{abstract}
Abstrak Pembelajaran daring pada masa pandemi Covid-19 membuat guru harus memutar otak untuk berinovasi dan kreatif dalam menyalurkan pengetahuan kepada peserta didik dengan berbagai cara. Penelitian ini dilakukan pada bulan Februari 2021 di SD Muhammadiyah 1 Ketelan Surakarta. Tujuan penelitian ini: 1) mengetahui implementasi strategi pembelajaran daring di era pandemi COVID 19 pada sekolah dasar; 2) mengetahui kesulitan yang dialami guru selama menerapkan pembelajaran daring di era pandemi COVID 19 pada sekolah dasar. Subjek penelitian ini adalah guru wali kelas IIID. Jenis penelitian ini merupakan studi kasus. Teknik pengumpulan data melalui wawancara terstruktur, observasi dan dokumentasi. Keabsahan data menggunakan trianggulasi data yaitu reduksi data, penyajian data, dan verifikasi. Hasil penelitian ini yaitu:1) Pembelajaran daring dilaksanakan sesuai kebijakan sekolah melalui zoom meeting setiap hari pada pukul 08.00-10.45 cukup efektif, hal ini dibuktikan berdasar nilai tengah semester yang menunjukkan rata-rata diatas batas minimum; 2) Kendala yang dialami selama pembelajaran daring di kelas adalah tidak optimalnya guru dalam menjelaskan materi, kendala signal dan masih ada beberapa peserta didik yang belum memiliki smartphone pribadi untuk mengikuti pembelajaran daring melalui zoom meeting dikarenakan smartphone dibawa oleh orangtua, sehingga guru selalu memberikan rekaman zoom meeting dan materi dalam bentuk file.
\end{abstract}

Kata Kunci : Pandemi Covid-19; Pembelajaran Daring; Sekolah Dasar 


\section{PENDAHULUAN}

Dunia saat ini sedang mengalami pandemi Corona Virus Diesease (COVID-19) yang telah melanda lebih dari 200 negara di Dunia termasuk Indonesia. Pada tanggal 2 maret 2020 sebanyak 2 kasus konfirmasi COVID-19 hingga sampai tanggal 16 maret 2020 meningkat sebanyak 10 orang dinyatakan positif corona (Saputra et al., 2020). Gejala umum di antaranya demam, batuk, dan sesak napas (Yuzar, 2020). Untuk mengantisipasi penularan virus tersebut pemerintah telah mengeluarkan berbagai kebijakan, seperti penerapan isolasi mandiri, social and physical distancing hingga pembatasan sosial berskala besar (PSBB).

Pandemi COVID-19 menyebabkan dampak pada semua sektor termasuk pada dunia pendidikan (Abidah et al., 2020). Pembelajaran tatap muka diberhentikan untuk sementara waktu, sehingga pelaksanaan kegiatan pembelajaran dilaksanakan secara daring. Hal tersebut tertuang dalam Surat Edaran Mendikbud Nomor 4 Tahun 2020 tentang pelaksanaan pendidikan dalam masa darurat COVID-19. Pembelajaran daring dilaksanakan dengan tujuan untuk memutuskan rantai penyebaran virus corona sehingga terjadi perubahan proses pembelajaran yang semua disekolah menjadi belajar dari rumah (Dewi, 2020). Pembelajaran daring adalah suatu strategi pembelajaran dimana pelaksanaanya menggunakan jaringan internet yang dilaksanakan secara tidak langsung antara peserta didik dan guru dengan pemberian materi pembelajaran (Asmuni, 2020). Pemberian materi dapat dalam bentuk teks, audio, gambar, animasi hingga video streaming serta aplikasi yang berbentuk website belajar melalui internet (Sri \& Krishna, 2014). Selain itu pemerintah juga menyiapkan beberapa acara TV dan radio serta penyediaan kuota gratis untuk memfasilitasi peserta didik dalam belajar (Muhammad, 2020). Melalui pembelajaran daring, peserta didik diharapkan tidak hanya mendengarkan uraian materi dari pendidik saja tetapi juga aktif mengamati, melakukan, mendemostrasikan, dan sebagainya (Pakpahan \& Fitriani, 2020).

Menurut Daheri et al (2020) media yang dapat digunakan pada saat pembelajaran daring, seperti Google Clasroom, Rumah Belajar, Edmodo, Ruang Guru, Zenius, Google Suite for Education, Microsoft Office 365 for Education, Sekolahmu, dan Kelas Pintar, platform tersebut disebut sebagai platform microbloging. Namun perlu waktu untuk mempelajari sistem tersebut, guru atau dosen sekalipun belum tentu paham penggunaan media-media ini. Apalagi orang tua dengan berbagai latar belakangnya, kesulitan untuk mempelajari media yang ada karena keterbatasan waktu. Maka guru harus bisa menggunakan berbagai media yang familiar digunakan orang tua dan siswa. Harapannya agar tidak mempersulit untuk orang itua dan siswa dalam penggunaan media tersebut, sehingga materi dari guru dapat tersampaikan dengan baik. Hal ini didukung berdasar 
Jenius: Jurnal of Education Policy and Elementary Education Issues

Vol.1, No.2, Desember 2020, pp. 54-62

penelitian yang dilakukan oleh Alaby (2020) yang menunjukkan bahwa salah satu media yang sangat dikenal oleh seluruh kalangan yaitu Whatsaap. Penggunaan Whatsapp sebagai media belajar banyak terjadi di tingkat sekolah dasar. WhatsApp dapat digunakan untuk mengirim pesan, video, telepon, dan video call. Platform lain yang dapat digunakan untuk mendukung pembelajaran dan banyak dikenal oleh semua kalangan adalah zoom meeting.

Penggunaan platform zoom meeting sebagai media pembelajaran daring cukup efektif dan banyak digunakan dalam proses pembelajaran secara virtual dan guru dapat menayangkan materi melalui share screen. Seperti pendapat Ismawati \& Prasetyo (2020) pada penelitiaanya bahwa penggunaan zoom meeting sangat mendukung kegiatan pembelajaran jarak jauh, sehingga peserta didik dapat menyerap materi yang disampaikan guru karena lebih nyata. Penelitian Rachman \& Erihadiana (2021) menunjukkan bahwa penggunaan platform zoom metting sangat mudah diakses melalui smartphone maupun personal computer sehingga peserta didik menjadi aktif dan mandiri ketika pembelajaran meskipun melalui jarak jauh. Sependapat dengan Naserly (2020) bahwa aplikasi zoom meeting sangat efektif digunakan dalam proses pembelajaran karena mumpuni untuk menampung lebih dari 20 orang.

Salah satu sekolah yang juga terkena dampak dari pandemi COVID-19 dan menerapkan penggunaan zoom meeting dalam mendukung pembelajaran daring adalah SD Muhammadiyah 1 Ketelan Surakarta. Berdasarkan hasil observasi, pembelajaran daring dengan menggunakan zoom meeting mulai diterapkan sejak adanya pandemi COVID-19, sehingga pembelajaran daring merupakan hal yang baru bagi civitas SD Muhammadiyah 1 Ketelan Surakarta. Pembelajaran daring yang mendadak ini menyebabkan belum adanya persiapan yang matang, baik dari guru, siswa maupun orang tua siswa. Beberapa guru mengalami kesulitan seperti kurang maksimalnya dalam menyampaikan materi, kendala signal dan belum semuanya memiliki smartphone pribadi. Tidak maksimalnya guru dalam menyampaian materi, kendala signal dan sarana prasarana ditakutkan akan berdampak pada capaian pembelajaran peserta didik.

Berdasarkan permasalahan yang yang dihadapi siswa di SD Muhammadiyah 1 Ketelan Surakarta tersebut, maka peneliti merasa perlu untuk menganalisis implementasi pembelajaran daring pada sekolah dasar, dan mengetahui kesulitan yang dihadapi guru selama pembelajaran daring selama pandemi COVID-19.

\section{METODE}

Jenis penelitian ini merupakan studi kasus, yang dianalisis secara deskriptif kualitatif. 
Jenius: Jurnal of Education Policy and Elementary Education Issues

Vol.1, No.2, Desember 2020, pp. 54-62

Penelitian dilakukan pada bulan Februari sampai April 2021 di SD Muhammadiyah 1 Ketelan Surakarta. Subjek penelitian merupakan wali kelas IIID. Uji keabsahan pada penelitian ini menggunakan triangulasi sumber dan triangulasi tenik. Teknik sumber digunakan untuk menguji kredibilitas melalui cara menggali informasi dari guru kelas, kepala sekolah, dan peserta didik. Triangulasi teknik menggunakan teknik wawancara, obervasi dan dokumentasi kemudian dianalisis menggunakan analisis model Miles and Huberman (Sidiq \& Mujahidin, 2019) yang terdiri dari: 1) reduksi data, data dan hasil observasi yang terkumpul yaitu penerapan pembelajaran daring sekolah dasar selama pandemi covid-19; 2) Penyajian data pada penelitian ini berupa hasil observasi, hasil wawancara dari peserta didik kelas IIID, guru kelas IIID, dan Kepala Sekolah tentang pembelajaran daring selama pandemi COVID-19, dan hasil dokumentasi nilai tengah semester peserta didik kelas IIID; 3) Verifikasi, berdasar data yang telah dikumpulkan ditarik kesimpulan objek yang dianalisis yaitu implementasi strategi pembelajaran daring dan kendala yang dihadapi guru ketika menerapkan pembelajaran daring selama pandemi COVID-19.

\section{HASIL DAN PEMBAHASAN}

Pandemi COVID-19 yang mengancam kesehatan dan menyebabkan angka kematian yang cukup tinggi (Walker et al., 2020) berdampak pada dunia pendidikan (Abidah et al., 2020) yang menyebabkan pembelajaran konvensional yang biasa dilakukan guru di sekolah harus diberhentikan sementara dan diubah dengan penerapan pembelajaran daring. Menurut Mustopa \& Hidayat (2020) bahwa pembelajaran daring menjadi salah satu solusi dengan proses belajar dari rumah masing-masing atau pembelajaran jarak jauh. Selain itu pembelajaran daring juga dapat mempersingkat waktu pembelajaran serta menghemat biaya operasional lembaga pendidikan karena keunggulan fleksibitas yang tinggi (Silahuddin, 2015). SD Muhammadiyah 1 Ketelan Surakarta merupakan salah satu sekolah dasar yang juga menerapkan pembelajaran daring sebagai salah satu solusi agar proses pendidikan tetap berjalan, namun tidak dipungkiri bahwa SD Muhammadiyah 1 Ketelan Surakarta juga mengalami berbagai kesulitan yang harus dihadapi selama pandemi ini. Berikut merupakan implementasi strategi penerapan pembelajaran secara daring selama pandemi dan kendala yang dihadapi guru selama pandemi COVID-19 di SD Muhammadiyah 1 Ketelan Surakarta.

\section{Implementasi Strategi Pembelajaran Daring Selama Pandemi COVID-19}

Umumnya suatu pembelajaran terjadi karena adanya proses interaksi antara peserta didik 
Jenius: Jurnal of Education Policy and Elementary Education Issues

Vol.1, No.2, Desember 2020, pp. 54-62

dan sumber belajar pada lingkungan belajar, dan dapat dilakukan dimana saja terutama di sekolahan. Namun tidak bisa dipungkiri bahwa tantangan pembelajaran semakin besar, mengingat kondisi saat ini adanya penyebaran COVID-19 tidak memungkinkan untuk melaksanakan pembelajaran secara tatap muka di sekolah. Pembelajaran daring/online merupakan alternatif untuk mengganti pembelajaran tatap muka, yang menggunakan perangkat atau alat bantu internet untuk dapat menghubungkan pendidik dan peserta didik. Seperti pendapat Suhery \& Jasmalinda (2020) bahwa pembelajaran daring merupakan sebuah proses kegiatan pembelajaran berbasis elektronik dengan menggunakan jaringan smartphone dan komputer. Saat ini sudah banyak sekali platform/media yang menyediakan fasilitas untuk mendukung pembelajaran antara pendidik dan peserta didik (Sandiwarno, 2016).

Menurut Daheri et al (2020) media/ platform yang dapat digunakan pada saat pembelajaran daring, seperti google classroom, ruang guru, rumah belajar dan banyak lagi lainya. Pembelajaran daring juga dapat dilaksanakan dengan menggunakan media sosial facebook dan Instagram (Kumar \& Nanda, 2019). Namun guru bahkan peserta didik membutuhkan waktu yang lama dalam mempelajari penggunaan media sosial dan berbagai macam platform pembelajaran. Salah satu platform yang mudah diterapkan dalam proses pembelajaran adalah zoom meeting.

Berdasarkan wawancara yang dilakukan di SD Muhammadiyah 1 Ketelan Surakarta, bersama kepala sekolah, peserta didik dan wali kelas diketahui bahwa zoom meeting merupakan platform yang digunakan sebagai pendukung pembelajaran secara daring. Proses pembelaaran daring dilakukan setiap hari dimulai pukul 08.00-10.45 WIB. Sebelumnya guru sudah menyiapkan materi terlebih dahulu sesuai RPP daring yang telah disusun untuk mempermudah pembelajaran daring berlangsung. Sehari sebelum pembelajaran guru selalu menginformasikan alamat zoom meeting dan materi apa yang akan dipelajari bersama. Pembelajaran dimulai dengan kegiatan awal salam, kemudian presensi kehadiran kemudian kegiatan inti menjelaskan materi, untuk lebih mempermudah pemahaman peserta didik guru menggunakan fasilitas voice, video, dan share screen untuk penyampaian materi. Setelah itu kegiatan akhir yaitu evaluasi, kesimpulan, penyampaian materi selanjutanya, penguatan pendidikan karakter, sampai kegiatan terakhir berdoa dilanjutkan dengan salam. Kepala sekolah selalu mengawasi selama pembelajaran daring berlangsung dengan cara memantau percakapan melalui whatsapp grup dan mengadakan briefing untuk guru satu minggu sekali untuk memberikan evalusi tentang kesulitan/kendala yang dialami selama pembelajaran daring sehingga jika ada kendala dapat cepat teratasi dengan baik. Berdasar hasil rekapitulasi Penilaian Tengah Semester (PTS) peserta didik yang memenuhi batas ketuntasan 
Jenius: Jurnal of Education Policy and Elementary Education Issues

Vol.1, No.2, Desember 2020, pp. 54-62

minimal (KKM) yaitu 72 sebanyak 31 peserta didik. Hal ini membuktikan bahwa platform zoom meeting cukup membantu dalam proses pembelajaran daring.

Meskipun selama proses pembelajaran daring, peserta didik kadang masih mencari informasi di google dan dibantu oleh orang tuanya. Dari sini dapat kita simpulkan bahwasanya, pembelajaran daring masih belum siap untuk diterapkan. Peserta didik masih belum bisa mandiri dalam belajar karena masih ada pengaruh orang tua yang membantu dalam proses pembelajaran. Karena pembelajaran daring dengan menggunakan teknologi merupakan sesuatu yang baru bagi peserta didik, sehingga peran orang tua dibutuhkan untuk mendampingi belajar peserta didik. Namun yang ditakutkan pendidik adalah, peran orang tua yang terlalu besar dalam membantu peserta didik belajar, seperti mengerjakan pekerjaan rumah (PR) dan tugas yang diberikan oleh pendidik semua dikerjakan oleh orang tua tanpa melibatkan peserta didik. Keterbatasan dalam penelitian ini belum menggali lebih dalam terkait peran orang tua dalam mebantu peserta didik dalam proses pembelajaran.

\section{Kendala Guru Selama Menerapkan Pembelajaran Daring Diera Pandemi COVID-19}

Peralihan pembelajaran dari yang semula tatap muka menjadi pembelajaran daring memunculkan banyak hambatan bagi guru, mengingat hal ini terjadi secara mendadak tanpa adanya persiapan sebelumnya. Berdasarkan hasil penelitian yang telah dilakukan terdapat beberapa kendala diantaranya pendidik tidak dapat menjelaskan secara optimal karena tidak bisa leluasa menjelaskan seperti berada di dalam kelas dan terbatasnya waktu pembelajaran online, beberapa peserta didik atau orang tua tidak memiliki smartphone sebagai fasilitas belajar online sehingga beberapa peserta didik bergabung dengan temannya, sedangkan beberapa peserta didik yang lain hanya mengandalkan smartphone yang sedang dibawa bekerja, sehingga tidak dapat mengikuti pembelajaran melalui zoom meeting secara maksimal. Pembelaran daring ini juga menyebabkan peserta didik bosan dan kadang sulit memahami materi yang disajikan guru. Menurut Anggianita et al (2020) kendala selama pembelajaran daring seperti ketersediaan sarana dan prasarana yang kurang memadai, perbedaan suasana saat belajar di kelas dengan belajar di rumah yang berpengaruh pada motivasi belajar peserta didik, serta kecenderungan gaya belajar daring yang visual dan tulisan sehingga menyebabkan peserta didik mudah bosan. Solusi pendidik dalam mengatasi masalah ketidakikutsertaan peserta didik dalam zoom meeting selama proses pembelajaran berlangsung yaitu dengan memberikan file hasil rekaman agar dapat dipelajari sendiri dirumah masing-masing.

Selama pembelajaran daring, guru, peserta didik, dan orang tua peserta didik merasa 
Jenius: Jurnal of Education Policy and Elementary Education Issues

Vol.1, No.2, Desember 2020, pp. 54-62

terbebani oleh kuota internet, terlebih lagi jika berada di kawasan yang terganggu signal, menyebabkan pemantauan perkembangan anak terbatas karena guru merasa tidak leluasa seperti di kelas. Hal ini juga didukung oleh penelitin Dewi (2020) mengemukakan pendapatnya bahwa kendala yang terjadi pada orangtua adalah banyaknya biaya kuota internet yang semakin bertambah, dan teknologi online memerlukan koneksi jaringan ke internet. Hal ini tidak mendukung bagi peserta didik yang rumahnya tidak terjangkau internet. Sedangkan, bagi peserta didik yang memiliki smartphone pribadi dikhawatirkan akan adanya penyalahgunaan ke hal negatif seperti bermain game yang berlebihan. Rigianti (2020) menambahkan kegiatan pembelajaran daring akan berjalan dengan baik dan lancar, jika peserta didik mendapat pengawasan, baik dari pendidik maupun orang tua. Hal tersebut merupakan penunjang kegiatan pembelajaran daring selama pandemi COVID-19.

\section{KESIMPULAN DAN SARAN}

\section{Simpulan}

Berdasarkan hasil penelitian dan pembahasan, maka dapat ditarik kesimpulan bahwa implementasi pembelaaran daring dibantu melalui platform zoom meeting. Penggunaan platform zoom meeting cukup efektif dalam proses pembelajaran daring pada sekolah dasar di SD Muhammadiyah 1 Ketelan Surakarta karena rata-rata nilai tengah semester peserta didik memenuhi batas ketuntasan minimal. Pada penelitian ini, proses pembelajaran berjalan dengan baik karena adanya kerjasama antara pendidik, peserta didik, dan orang tua peserta didik, namun peran orang tua dalam membantu proses pembelajaran peserta didik perlu dikaji lebih lanjut oleh praktisi dan peneliti pendidikan.

Kendala yang dihadapi oleh pendidik ketika menyampaikan materi selama pembelajaran daring yaitu tidak optimalnya pendidik dalam menjelaskan materi karena waktu yang sangat singkat sehingga tidak bisa leluasa seperti menjelaskan ketika berada di dalam kelas. Jaringan internet yang kurang stabil, dan peserta didik yang tidak memiliki smartphone pribadi untuk bergabung zoom meeting juga menjadi kendala pendidik dalam menyampaikan materi pembelajaran. 


\section{DAFTAR PUSTAKA}

Abidah, A., Hidaayatullaah, H. N., Simamora, R. M., Fehabutar, D., \& Mutakinati, L. (2020). The impact of covid-19 to indonesian education and its relation to the philosophy of "merdeka belajar". Studies in Philosophy of Science and Education, 1(1), 38-49.

Alaby, M. A. (2020). Media sosial whatsapp sebagai media pembelajaran jarak jauh mata kuliah ilmu sosial budaya dasar (ISBD). Ganaya: Jurnal Ilmu Sosial dan Humaniora, 3(2), 273-289.

Anggianita, S., Yusnira, Y., \& Rizal, M. S. (2020). Persepsi guru terhadap pembelajaran daring di sekolah dasar negeri 013 Kumantan. Journal of Education Research, 1(2), 177-182.

Asmuni, A. (2020). Problematika pembelajaran daring di masa pandemi covid-19 dan solusi pemecahannya. Jurnal Paedagogy, 7(4), 281-288.

Daheri, M., Juliana, J., Deriwanto, D., \& Amda, A. D. (2020). Efektifitas whatsapp sebagai media belajar daring. Jurnal Basicedu, 4(4), 775-783.

Dewi, W. A. F. (2020). Dampak covid-19 terhadap implementasi pembelajaran daring di sekolah dasar. Edukatif: Jurnal Ilmu Pendidikan, 2(1), 55-61.

Ismawati, D., \& Prasetyo, I. (2020). Efektivitas pembelajaran menggunakan video zoom cloud meeting pada anak usia dini era pandemi covid-19. Jurnal Obsesi: Jurnal Pendidikan Anak Usia Dini, 5(1), 665-675.

Keputusan Menteri Pendidikan dan Kebudayaan No.4 Tahun 2020. Pelaksanaan kebijakan pendidikan dalam masa darurat penyebaran coronavirus disease (COVID-19). Surat Edaran dari Kementerian RI, 2020. Retrieved from https://pusdiklat.kemdikbud.go.id/surat-edaranmendikbud-no-4-tahun-2020-tentang-pelaksanaan-kebijakan-pendidikan-dalam-masadarurat-penyebaran-corona-virus-disease-covid-1-9/

Kumar, V., \& Nanda, P. (2019). Social media in higher education: A framework for continuous engagement. International Journal of Information and Communication Technology Education (IJICTE), 15(1), 97-108.

Muhammad, H. (2020). Menyiapkan pembelajaran di masa pandemi: Tantangan dan peluang. Kementerian Pendidikan dan Kebudayaan.

Mustopa, A. J. M. J., \& Hidayat, D. (2020). Pengalaman mahasiswa saat kelas online menggunakan aplikasi zoom cloud meeting selama covid-19. Journal Digital Media \& Relationship, 2(2), 75-84.

Naserly, M. K. (2020). Implementasi zoom, google classroom, dan whatsapp group dalam mendukung pembelajaran daring (online) pada mata kuliah bahasa inggris lanjut (studi kasus pada 2 kelas semester 2, jurusan administrasi bisnis, fakultas ekonomi dan bisnis, universitas bina sa. Aksara Public, 4(2), 155-165.

Pakpahan, R., \& Fitriani, Y. (2020). Analisa pemanfaatan teknologi informasi dalam pembelajaran jarak jauh di tengah pandemi virus corona covid-19. Journal of Information System, Applied, Management, Accounting and Research, 4(2), 30-36.

Rachman, T. A., Latipah, E., \& Erihadiana, M. (2021). Evaluasi penggunaan aplikasi zoom meeting dalam program tahfizh al-qur'an di sd khoiru ummah cianjur. Jurnal Pendidikan dan Pengajaran Guru Sekolah Dasar (JPPGuseda), 4(1), 01-06.

Rigianti, H. A. (2020). Kendala pembelajaran daring guru sekolah dasar di kabupaten Banjarnegara. Elementary School: Jurnal Pendidikan dan Pembelajaran Ke-SD-an, 7 (2), 297-302.

Sandiwarno, S. (2016). Perancangan model e-learning berbasis collaborative video conference learning guna mendapatkan hasil pembelajaran yang efektif dan efisien. Jurnal Ilmiah FIFO, 8(2), 191.

Saputra, M., Arsyi, M., Nurhanifah, N., Octavia, S. N., \& Pratomo, H. (2020). Evaluasi pedoman penanganan cepat medis dan kesehatan masyarakat tentang coronavirus disease (covid-19) di indonesia. Jurnal Ilmiah Ilmu Keperawatan Indonesia, 10(02), 8-17. 
Jenius: Jurnal of Education Policy and Elementary Education Issues

Vol.1, No.2, Desember 2020, pp. 54-62

Sidiq, U., Choiri, M., \& Mujahidin, A. (2019). Metode penelitian kualitatif di bidang pendidikan. Journal of Chemical Information and Modeling, 53(9).

Silahuddin, S. (2015). Penerapan e-learning dalam inovasi pendidikan. CIRCUIT: Jurnal Ilmiah Pendidikan Teknik Elektro, 1(1).

Sri, K. U., \& Krishna, T. V. (2014). E-learning: technological development in teaching for school kids. International Journal of Computer Science and Information Technologies, 5(5), 6124-6126.

Suhery, S., Putra, T. J., \& Jasmalinda, J. (2020). sosialisasi penggunaan aplikasi zoom meeting dan google classroom pada guru di sdn 17 mata air padang selatan. Jurnal Inovasi Penelitian, 1(3), 129-132.

Walker, P., Whittaker, C., Watson, O., Baguelin, M., Ainslie, K., Bhatia, S., ... \& Ghani, A. (2020). Report 12: The global impact of covid-19 and strategies for mitigation and suppression.

Yuzar, D. N. (2020). Penyakit menular dan wabah penyakit covid-19. Retrieved from https://osf.io/5bqvw. 